\title{
Fiqh Science Factors of Difference of Opinion (Analysis of the Relationship with Humans and Its Nature of Needs)
}

\section{Riyandi S.}

IAI Al-Aziziyah Samalanga, Aceh, Indonesia

\begin{abstract}
Islam is a religion of rahmatan lil'alamin, in which various kinds of religious laws have been regulated, ranging from social issues to spiritual issues, where legal issues relating to humans are wrapped in a scientific discipline, namely the science of fiqh. This phenomenon can be seen clearly from the works of previous scholars, in which one of the problems of Islamic law is worship, mu'amalat munakahat and jinayat or in figh it is called rubu 'systematically structured science, this paper discussing the science of fiqh and the factors for the occurrence of differences of opinion among the imams school, the author uses a qualitative methodology using a historical opproach approach in order to provide data validity about the development of figh science. History records that fiqh has appeared since the time of Rasulullah SAW (fiqih waqi' amali) and the time of the Companions. Fiqh developed gradually and preodised until it became a discipline rich in its ushul fiqh methodology. The main factor in the emergence of differences of opinion among the Imam of the Schools was due to their differences in translating Nash Al-Qur'an and Hadith as well as legal issues that were not contained in the Nashnya in the Al-Qur'an or Hadith by focusing on one discipline of Ushul Fiqih through the istimbat methodology through the Ijtihad of each Imam School. The relationship between figh and human deeds is always contaminated and cannot be separated from the problem of worship, because humans began at the time when they were subjected to the law of syara ', like it or not, humans have to deal with legal issues (khitabullah). The essence of human need is to get a life that is truly holy in the world and the hereafter, when viewed from the real side of life, humans need a life that is safe, peaceful, prosperous, just and safe. This can be felt and enjoyed if the human has knowledge.
\end{abstract}

Keywords

fiqh science, relationship with humans and its nature; difference of opinion

\section{Introduction}

We both know that in the beginning of Islam there were no schools and no sects, and at the beginning of Islam, Islam was clean from outside influences, and the Muslims at that time reached their glory. It is also known with certainty that the existence of sects and schools of thought can divide the Muslims, and can sharpen the gap between them, because with it, it is impossible for them to formulate their strength and organize joint steps to formulate a single path to achieve one goal.

Daily human activities in the world are inseparable from the law of Allah SWT, humans are given reason by Allah as a form of perfection, with that reason humans can think deeply about Allah's laws, but in exploring Allah's laws which are so broad as found in the Al-qur'an, the mujtahid Mutlaq Abu Hanifah, Imam Malik, Imam Shafi'i and Imam Hanbali took new steps in translating the contents of the verses of the Al-Qur'an, namely Ijtihad. 
Believe it or not, that human beings cannot be separated from the law of fiqh, since the Balinese and there is also the law of fiqh starting to work in managing human problems, until people die, the issue of fiqh still has a relationship, but the relationship focuses more on people who are still alive. According to Helmi et al (2019) One form of the development of fiqh is to make the charge of fiqh in the form of theoretical laws into practical laws by putting them in the legislation of a certain State or territory in the State.

In order to strengthen a science that we have recognized as valid, it is also necessary to extract information about the history of its development, so in this paper the author also reviews a little historical priodization of the science of fiqh itself.

One of the factors in the birth of the mu'tabar school was due to the intelligence possessed by the Imams of the School and the geographic regional factor which required the imams to observe Islamic laws regarding fiqh in accordance with the conditions and situation of society at that time.

Based on the above phenomena, with all the limitations of the writer's understanding, the author will try to put a little thought into this paper about Fiqh Science and the factors why there are differences of opinion among the four Imam of the Schools.

The writing of this paper is certainly not free from mistakes and mistakes, hope, I hope friends can correct it and ask to be forgiven for all these mistakes and mistakes. Hopefully what we do will become deeds of worship in yaumil mahsar in the future. Amen

\section{Review of Literatures}

\subsection{Understanding Fiqh Science}

Fiqh in terms of Shara 'is: Knowledge of Islamic sharia laws regarding human actions, which are taken from their detailed arguments. Or in other words: jurisprudence or a collection of Islamic shari'a laws regarding human actions, which are taken from their arguments in detail (Abdul Wahab Khallaf, 2000). While fiqh has another meaning, as Ahmad Hasan said in his book Pintu Ijtihad Before Closed. Fiqh is: A small circle, which deals with what is generally understood as legal acts in a more specific sense that fiqh is merely concerned with law. According to Nasution and Dayu (2020) If you examine all the commands and prohibitions of Allah in the Qur'an, as well as the commands and prohibitions of the Prophet SAW in the sunnah formulated in figh, it will be seen that all of them have a specific purpose and nothing is in vain.

From the understanding of the science of fiqh above, according to the author's analysis, in general, the science of fiqh contains two main things, the first is the science that regulates the actions of humans with Allah SWT. The second science that regulates aff'al among humans and with other creatures.

\subsection{Periodization of the Birth of Fiqh Science}

Tells the story of the historical periodization of the birth of the science of fiqh, basically the science of fiqh grew and began to develop during the time of the Prophet Muhammad himself, because the Prophet was the one who had the right and authority to teach Islamic law. In the book Tasyri's Date 'it is usual to explain the periodization of the history of fiqh on the basis of the characteristics and things that stand out at a certain time (HA Djazuli, 2006). Below the author will describe a little of the situation and conditions of the birth of the Fiqh of the Mecca and Medina phases.

This initial period can be divided into two phases, namely: the Mecca phase and the Medina phase. In the Mecca phase, the Muslim ummah was still few and still weak, unable to form itself as an ummah that had strong sovereignty and power (Shiddieqy, 1999). 
During this period the Prophet Muhammad's message was more focused on the issue of aqidah. There are not many verses of law that came down during this period, and even then they are still in a series of realizing aqidah revolution to change the belief system of the people of Jahiliyah towards servitude to Allah SWT alone.

In the Medina phase, the Islamic ummah developed rapidly and had their own governance, so that the media of preaching took place safely and peacefully. Conditions like this are what encourage the formation of laws that regulate the relationship between individuals of a nation and other nations, and regulate communication contacts between Muslims and non-Muslims, both in times of peace and in times of war (Wahab Khallaf, 2001).

Therefore, social laws cover the fields of marriage, inheritance, covenants, accounts payable, criminal law, and others.

Fiqh at the time of the Prophet Muhammad was Fiqih Waqi 'Amali, meaning that the law was discussed after an event (seeking law after the incident). So fiqh at this time is practical and not theoretical, where friends ask for fatwas and ask questions about the law after an incident. So the syari'atan method at this time uses the method; first, syari'atan which was preceded by questions from friends, because of their need for law; second, syari'atan which is revealed without any questions from friends (without a cause).

In this period Rasulullah SAW was the main figure who became a legal role model for the companions in understanding everything. Rasulullah SAW conveyed what he received from Allah SWT and explained it to them both aspects of worship and muamalah. Thus it is clear that at this time there were no disputes in the laws of the many laws.

Historical scientists share the historical priodization of fiqh with different opinions, including Khudarai Bek, he divided into six periods, namely:

1. Islamic law at the time of the Prophet Muhammad

2. Islamic law at the time of the great Companions

3. Islamic law at the time of the little friends

4. The Islamic law of the era of fiqh has become an independent science

5. The Islamic law of the age of debate to defend each Imam

6. Islamic law in the taqlid era.

Meanwhile, Muhammad Ali As-Sayis divided it into six priorities. According to Muhammad Salam Madkur's opinion, the historical period of fiqh is divided into five periods.

After we look at the historical priodization of the birth of the jurisprudence as stated by the three scholars above, the authors conclude that fiqh grew and developed into five priodizations, namely: First: Fiqh at the time of the Prophet Muhammad. Second: Fiqh during the time of Khulafa al-rasyidin. Third: Fiqh during the time of Tabi'in until the birth of the School of Fiqh. Fourth: Fiqh during the Taqlid period. Fifth: Fiqh after the Taqlid period.

\section{Discussion}

\subsection{Factors for the Emergence of the School}

Since the death of Prophet Muhammad SAW, Allah SWT's revelation was interrupted, he left two main teachings of Islam, namely the Al-Qur'an and Sunnah as the guidance of the Islamic ummah, then the baton of the leadership of the Islamic ummah was continued by Khulafa al-Rasyiddin starting from the Caliph Abu Bakr Siddiq, Umar Bin Khatab, Usman Bin Affan and Ali bin Abi Talib, then the science of fiqh continues to grow and develop from the time of companions to the time of tabi'in from the tabi'in period to 
the time of tabi 'tabi'in, from the time of tabi' tabi'in to to the time of the birth of the fiqh schools, since the birth of the four schools of figh, then fiqh in the taqlid period until now.

At a glance the sects of the jurisprudence above, the following will discuss the factors of the birth of the four schools, namely the Abu Hanifah School (died $150 \mathrm{AH}$ ), the Malik School (died 179 H), the Shafi'I School (died 204) and the Ahmad Bin Hanbal School (died. 241).

This period began in the second century $\mathrm{H}$ and ended in the middle of the fourth century $\mathrm{H}$, the development process lasted for 250 years. This period is called the period of scheduling or bookkeeping, because it was during this period that the movement of writing and bookkeeping Islamic laws experienced very rapid development and progress. The hadiths of Prophet Muhammad SAW, fatwas of friends and various scientific treatises have been codified in a form of bookkeeping (Waliyullah Al-Dahlawi, 1995).

This period is the golden period in the history of the formation of Islamic law. Islamic law has developed and matured to produce a legal treasury. Besides that, the area of Islamic dominion is increasingly expanding, all problems in the life of the ummah also face obstacles from various sectors where these obstacles need answers to Islamic law, this obstacle also made fiqh experts at that time more productive in producing their ijtihad which was sourced from the Qur'an and Sunnah. According to Siahaan et al in Arief (2020) Islamic education is education based on the Koran and As-sunah, always has scientific goals that have the aim of making humans as halifahs who can carry out their duties properly

At this time the jurisprudence experts really became the center of the foundation of the ummah, starting from the lower class of society to state officials, the Abbasid caliphs provided enormous support for the development of science, and made the scholars as a place of reference in all matters. So that the jurisprudence experts gave birth to their thoughts and packaged them in the form of a Maazhab.

It is thus clear that the factor of the birth of the School was caused by several factors, including: the factor of the expansion of the territory of Islam, the emergence of various life problems that needed answers to Islamic law where this problem, when examined by the Imam of the School, could not find a detailed text in Al- The Qur'an and Sunnah, the emergence of differences of opinion between the Fuqaha 'and the emergence of figures who have talents and abilities that are very apt, such as Abu Hanifah, Imam Malik, Imam Syafi'i and Ahmad Bin Hanbal.

\subsection{Reasons for Dissent}

The jurisprudence that has been packaged by Mujtahid imams, in compiling the contents of the systematic jurisprudence, the mujtahid imams look for steps in revealing the law that comes from the texts of the Al-Qur'an or Hadith, there is no shift in the meaning and content of the verses of the Al-Qur'an.

So one of the methods adopted by Mujtahid imams in breaking the law is to use the istimbat method. The substance of the four contents of this fiqh is similar to one another and there are also differences of opinion between these four schools of thought. The difference of opinion is relative, showing that there is a clear color from the four imams Mujtahid, so below the author will describe the reasons why there are differences of opinion between these four schools.

According to Ali Khafif (1956) One of the reasons for the difference in opinion among the priests of the School was due to several main factors, namely:

1. The difference of opinion factor in understanding Nash Al-Qur'an

2. Factors in certain cases where the Nashnya was not found, either Al-Qur'an or Hadith 
3. The legal difference factor is because it is seen from a different point of view

4. The difference in the use of Ra'yu

5. The difference regarding the determination of part of the source of law

6. Geographical factors where each Mujtahid Imams domiciled

Of the six factors that caused the disagreement of the priests of the above Schools, the Schools which were developed to this day were born. The followers of each school always maintain and preserve the work of the Imam of the School, and always make life guidelines in worshiping Allah SWT.

According to the author, the tendency for differences of opinion among the Imam Mujtahid was caused by the stipulation of istimbat or ijtihad as legal arguments, in which Istimbat and Ijtihad of the Mujtahids were formulated as a methodology of Usul Fiqih in exploring syar'i laws.

Disputes over the opinion of Imam Mujtahid not only occur in the torso sector of the Qur'an as a legal argument but also exist in the realm of Hadith, one example of this is: Such as the way of accepting Hadith and the bases used to clarify the Hadith, for example: Abu Hanifah and Ashab-Ashabnya only collided with sunnah mutunggurahand mayhurah only, and describe the hadiths that were narrated by the fuqaha'-fuqaha 'they believed in. It is different with Imam Malik and Ashab who recited the hadiths narrated by the Ulama of Medina, and abandoned the traditions of Sunday which violated the practice of the scholars of Medina. Meanwhile, Imam Shafi'i collided with the hadith on Sunday with the condition that it was narrated by a fair and reliable narrator, whether in accordance with the practice of the Medina scholars or not (Hasbi Ash Shiddieqy, 1999).

\subsection{Fiqh and its Relationships with Human Relationships and its Property Needs}

Fiqh science is one of the legal channels that lead people to get the happiness of life in this world and the hereafter. to Allah SWT. Since he was conquered by khitabullah, when he was conquered by law, then the problem of fiqh cannot be separated from his life, because the law of syara 'is khitabullah that must be obeyed and obliged to be practiced.

Humans as dimensional beings have a very noble role and position. Humans who have existence in their lives as: (1). abdullah, (2). an-nas, (3). al insan, (4). al basyar and (5). caliph. For example, as a caliph on earth as a substitute for God, man here must be in touch with history and make history by developing the essence of curiosity to make him creative and encouraged by transcendent values. Humans with God have a position as servants. Humans and other humans have a balanced correlation and cooperate with each other in order to prosper the earth. Humans and their natural surroundings are a means of increasing knowledge and gratitude towards God and are tasked with making nature a subject in order to get closer to God.

In essence, the goal of man in carrying out his life is to reach reunion with his Creator. The reunion is like the return of sea rain. The return of man according to his origin as in the human dimension that comes from the Creator, then he returns to God in accordance with his form, for example in the form of immaterial then returns to the lover in the form of immaterial while the material elements that are in man will return to the material that forms the human body. The encounter of man with God is in the stage of the nafs, which is spiritual because the spiritual nafs is very beautiful and God will call him back to that nafs with him. The nafs that is owned by humans is the limited nafs that will return with the absolute and unlimited nafs, and the return of the human nafs through monotheism between faith and righteous deeds. Therefore, humans are divine beings. (Asy'ari, 1999). 
The essence of man must be seen at the stages of the nafs, ego, self, ego, where at this stage all the elements form an actual, present and dynamic self-unity, and the dynamic present-day actualization that is in their actions and deeds. Conceptually, humans are better because humans have knowledge, intelligence, abilities and are creative. At the naf stage, the essence of man is determined by his deeds, works and deeds, while in tawhid, the essence of man and his function of man as' adb and khalifah and the actualization unit as a unit of body and spirit that forms at the actual stage of the nafs. (Asy'ari, 1999).

In principle, humans are creatures of a moral nature which contain an effort. This is where humans need to accept the world outside of themselves. This attitude makes people aware of themselves and make various efforts. Humans generally refer to human nature itself. According to Kierkegaard, man is his own state or existence itself. However, human existence is not a "being" but a "being", which contains in it a transfer, that is, a transfer from "possibility" to "reality". Human existence is an existence chosen in freedom. To exist means to have the courage to make life-defining decisions. Each existence has its own unique characteristics. Kierkegaard distinguishes the existence of 3 forms of existence, namely: (1) aesthetic form, (2) ethical form and (3) religious form. (Abidin, 2000)

Based on this description, it can be concluded that the human dimensions are: (1) humans as individual beings, (2) humans as social creatures, (3) humans as moral creatures, and (4) humans as divine beings.

\section{Conclusion}

From some of the discussions above, it can be concluded that several conclusions are:

1. History records that fiqh has appeared since the time of Rasulullah SAW (fiqih waqi 'amali) and the time of the Sahaba, then fiqih developed gradually and preodised until it became a discipline rich in its ushul fiqih methodology.

2. The development of fiqh grew and developed rapidly from the time of tabi'in to the birth of the Imam of the Schools

3. The main factor in the emergence of differences of opinion among the Imam of the Schools was due to their differences in translating Nash Al-Qur'an and Hadith as well as legal issues that were not contained in the Nashnya in the Al-Qur'an or Hadith by focusing on one discipline of Ushul Fiqih through the istimbat methodology through the Ijtihad of each Imam School.

4. Based on humans as God's creatures, there are several human dimensions, including: (1) humans as individual beings, (2) humans as social beings, (3) humans as moral beings, and (4) humans as divine beings.

5. When viewed from the point of view of the essence of the necessities of human life, it is necessary to live a safe, peaceful, and serene life and get the happiness of the world and the hereafter. 


\section{References}

Abdul Wahab Khallaf. (2000) Kaidah-Kaidah Hukum Islam (Ilmu Ushulul Fiqh), Edition VII. (Jakarta : Raja Grafindo Persada).

Ahmad Hasan. (1414.H-1994.M) Pintu Ijtihad Sebelum Tertutup (Bandung : Edition II). Ali Khafif. (1956). Mahadaratul Al-Asbab al-Ikhtilafil Fuqaha’. Arabiyah: Page 108.

H.A. Djazuli. (2006). Ilmu Fiqih Penggalian Perkembangan dan Penerapan Hukum Islam. Edition VI. (Jakarta : Kencana Prenada Media Group).

Hasbi Ash Shiddieqy. (1999). Pengantar Ilmu Fiqih. Page 67-68.

Helmi, et al. (2019). Implementation Place of 'Uqubat Canings in Fiqh Perspective (Analysis of Aceh Governor Regulation Number 5 of 2018). Budapest International Research and Critics Institute-Journal (BIRCI-Journal), 65-73.

Muhammad Ali As-Sayis. (2003). Sejarah Fikih Islam. Translate by Nurhadi AGA. (Jakarta : Pustaka Al-Kautsar).

Muhammad Khudari Bek. (1968). Tarikh Tasyri' AL-Islam (Jedah-Al-Haramain.tt).

Muhammad Salam Madkur. (1960). Al-Madkhal li al-Fiqh al Islami Tarikuhu Wamashadiruhu Wa Nazhiriyatuhu al-Ammah. Edition I. (Dar al-Nahdhah alArabiyah).

Nasution, M., S., A., Dayu, W. (2020). Fiqh Fardhu Kifayah for the City of Covid-19 According to the Fatwa of MUI and Permenkes Number 413 (Maqashid Syariah Analysis). Budapest International Research and Critics Institute-Journal (BIRCIJournal), 3005-3016.

Siahaan, et al. (2020). Innovation of the Use of Education Games Method Utilizing a Thousand of Nail Media in Fiqh Lesson Madrasah Ibtidaiyah Amaliyah Pematangsiantar District. Budapest International Research and Critics in Linguistics and Education (BirLE) Journal, 1558-1563.

Teungku Muhammad Hasbi Ash Shiddieqy. (1999). Pengantar Ilmu Fiqih. Edition II. Cet. (Semarang : Pustaka Rizki Putra).

Wahab Khallaf. (2001). Sejarah Pemebentukan dan Perkembangan Hukum Islam. Diterjemahkan oleh Wajidi Sayadi. Edition I. (Jakarta : Raja Grafindo Persada).

Waliyullah Al-Dahlawi. (1995). Lahirnya Mazhab-Mazhab Fiqih. Diterjemahkan oleh Mujiyo Nurkholis. Edition IV. (Bandung: Remaja Rosdakarya). 